\title{
THE CONVERSION OF HEMATIN TO BILIRUBIN FOLLOWING INTRAVENOUS ADMINISTRATION IN HUMAN SUBJECTS ${ }^{1}$
}

\author{
By I. J. PASS,2 S. SCHWARTZ, AND C. J. WATSON \\ (From the Department of Medicine, University of Minnesota Hospital, Minneapolis)
}

(Received for publication October 9, 1944)

The results of earlier studies of the fate of hematin in the animal organism have been contradictory (1). Some have found that hematin, as well as hemoglobin, was converted quantitatively into bilirubin in bile fistula dogs (2). Partly as a result of this work and possibly also because of the ease with which hemoglobin is converted to hematin in vitro, it became rather generally accepted that hematin was intermediate in the pathway from hemoglobin to bilirubin. The studies of others ( 3 to 7$)$ have indicated, however, that the transition is over a "green" hemoglobin, or biliverdin-iron-globin, rather than over hematin. Thus the present question is not so much whether hematin is a normal precursor of bilirubin, but whether, once formed under abnormal conditions, it is capable of conversion to bilirubin in vivo. This question is of considerable fundamental significance because of the presence of hematin in the circulating blood in a variety of pathological states such as gas bacillus sepsis, pernicious anemia, hepatic disease $(8,9)$, severe malaria, and blackwater fever $(8,10)$. As Fairley $(10)$ has shown, hematin in the circulating blood is bound to the serum albumin, a compound which he has designated as "methemalbumen." The fate of hematin is also of considerable interest because of its probable identity with the so called "malarial pigment" (11).

Certain investigators in recent years have dissented from the view that hematin is converted to bile pigment. Bingold (12) and Duesberg (9), in particular, have designated hematin as a "blind alley" in hemoglobin metabolism. The literature pertaining to this question was reviewed in 1938 (1) so that this need not be given in more

1 Aided by a grant from the Medical Research Fund, Graduate School, University of Minnesota.

2 Dr. Pass was killed in an automobile accident . in 1939. At that time, he had completed investigations which were to have been compiled as a thesis for the $\mathrm{Ph} . \mathrm{D}$. degree in Medicine. The present report includes a part of these studies. detail at present. It is desirable, however, to refer in some detail to Duesberg's studies (9) since these have provided the most concrete experimental data favoring Bingold's concept. Duesberg (9a) found that hemoglobin was promptly converted to bilirubin when injected either into the circulating blood or into ascitic fluid within the peritoneal cavity. On the contrary, no evidence of conversion of hematin to bilirubin was noted under like conditions. To anticipate the criticism that the injected hematin might have been converted to bilirubin, and then at once excreted by the liver, Duesberg used subjects with complete biliary obstruction, reasoning that if there were conversion in such individuals the bilirubin level should increase. Actually, increases were noted after hemoglobin injection, but not after hematin. In other experiments in non-jaundiced individuals, Duesberg did not find any increase of bilirubin in the bile following intravenous injections of hematin. Obviously, it was not possible to obtain data over long periods of time nor to control the factor of varying dilution of the bile in these studies. The determination of urobilinogen excretion in the feces would have been preferable, but this was not followed. So far as can be determined, Gitter and Heilmeyer (13) are the only investigators who injected hemoglobin and hematin and then determined the amount of urobilinogen in the feces. Gitter and Heilmeyer found that hemoglobin injection was regularly followed by increased urobilinogen excretion, quite in accord with previous observations. Their data for the hematin experiments, however, were inconclusive. For the most part, a definite increase of urobilinogen was not observed.

It may be noted that Duesberg and Hagenbeck (14) observed the appearance of hematin in the plasma after intravenous injection of hemoglobin in subjects with liver disease, especially severe cirrhosis of the liver. They regarded this, in fact, 
as a means of testing liver function, since hematin did not appear in the normal subjects receiving hemoglobin intravenously.

The purpose of the present investigation was to observe the serum bilirubin after injections of hemoglobin and hematin, in subjects without evidence of liver or biliary tract disease and in patients with complete biliary obstruction, and to determine the urobilinogen excretion in the feces of the former group in order to ascertain whether hemoglobin and hematin injections are followed by equal increase or whether hemoglobin alone is converted to bile pigment.

\section{MATERIAL AND METHODS}

Crystalline hemin was prepared from washed human red blood cells according to a modification of Schalfejeff's method (15). The crystals as obtained from glacial acetic acid were washed repeatedly with water and were recrystallized from pyridine chloroform (15). The solutions of hematin injected intravenously were prepared by dissolving the crystalline hemin in $10 \mathrm{ml}$. of 5 per cent sodium carbonate which had just been brought to the boiling point. The solution was then diluted to $50 \mathrm{ml}$. with sterile distilled water, making a concentration of approximately 1 per cent carbonate. The amount of hematin dissolved varied between 100 and $750 \mathrm{mgm}$. as noted in Figures 1 to 12 . The oxyhemoglobin solutions which were used were prepared in eách instance from the blood of the individual under investigation. The red blood cells were washed repeatedly with sterile physiological saline and were then laked with sterile distilled water. Under sterile conditions the hemolyzed blood was then centrifuged at 3000 R.P.M. for one half hour after which the supernatant hemoglobin solution was carefully taken directly into a large sterile syringe from which it could be given intravenously. A small measured portion was removed for hemoglobin determination, which was carried out with a Zeiss stufenphotometer, according to Heilmeyer's method (16).

Hematin was administered intravenously in 11 subjects. Four of these were normal individuals, 1 suffered from spontaneous hypoglycemia, and 1 from chronic glomerulonephritis (without uremia). Four had complete biliary obstruction due to cancer of the extrahepatic biliary tract. One had a complete external biliary fistula as a result of a secondary operation for benign (postoperative) common duct stricture. In separate experiments, oxyhemoglobin was also administered

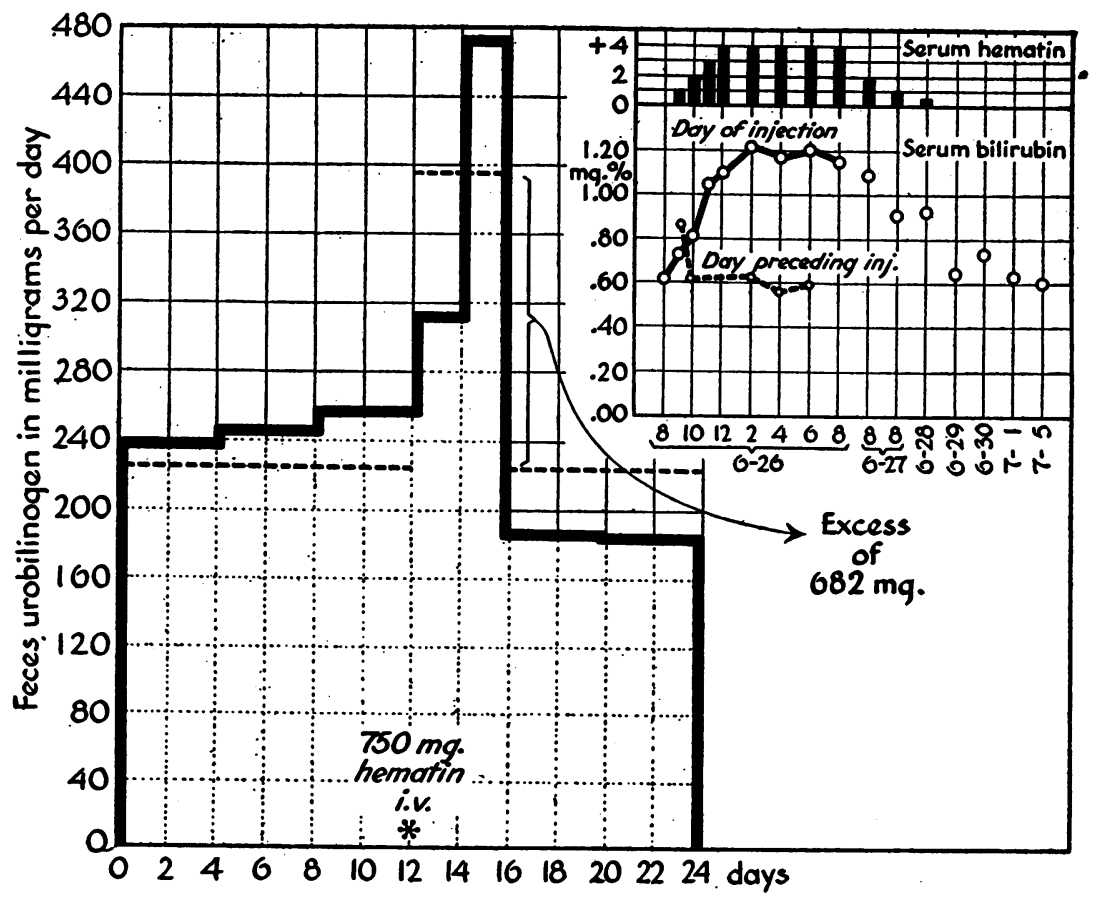

Fig. 1. Intravenous Injection of Hematin in a Normal Male Subject, W. Z., AgE 24

The increase of the feces urobilinogen roughly corresponds in amount with the injected hematin. The higher levels of serum bilirubin and the long persistence of hematin in the serum, after the injection, may be noted. 


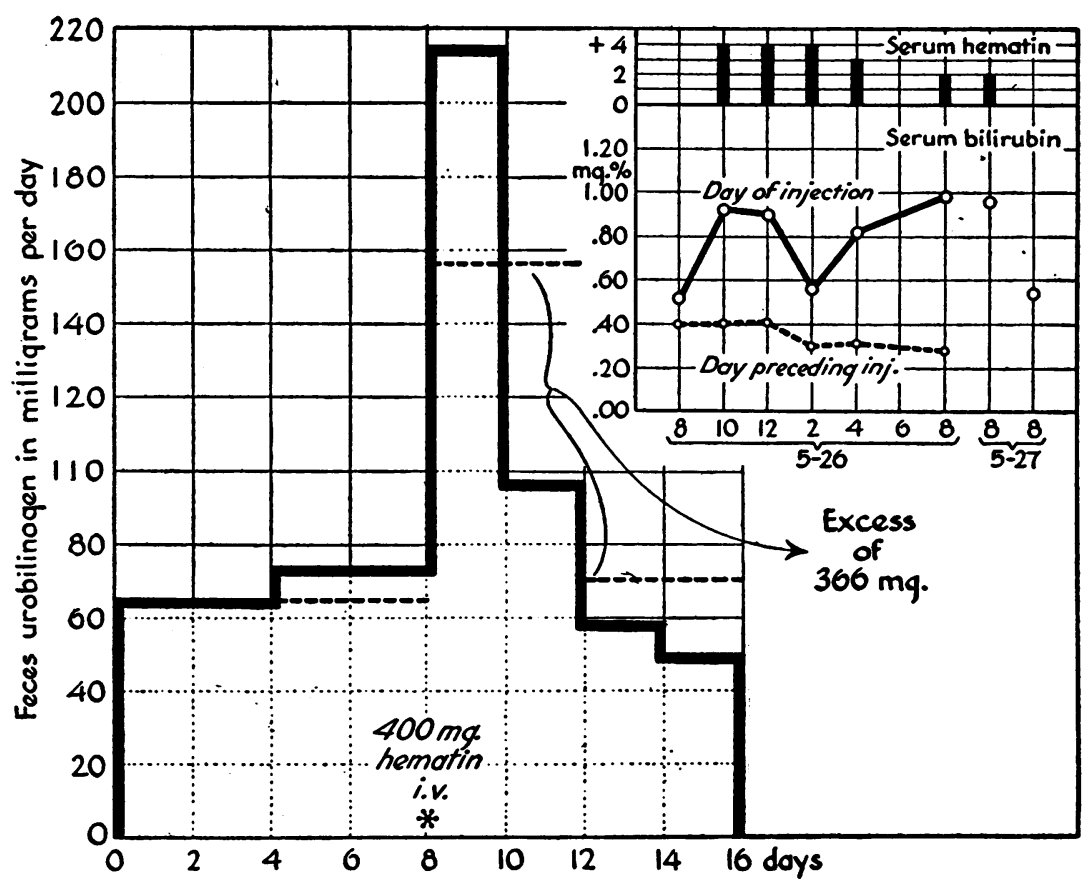

Fig. 2. Intravenous Injection of Hematin in a Normal Female Subject, E. S., Age 21

The increase of the feces urobilinogen, roughly corresponding in amount to the injected hematin may be noted, together with the higher levels of serum bilirubin and long persistence of hematin in the serum.

intravenously to 3 of these subjects, including the patient with hypoglycemia, 1 of the normal individuals, and 1 of the cases of complete biliary obstruction.

Bilirubin in serum and urine was determined with the stufenphotometer by a modification (17) of the Jendrassik-Czike technique (18).

Hematin in the serum was followed by means of conversion to hemochromogen, effected by addition of a few drops of ammonium sulphide, the characteristic hemochromogen absorption band at $557 \mathrm{~m} \mu$ being observed in a Zeiss grating spectrometer. No attempt was made to quantitate the hemochromogen absorption in these studies. The relative intensity of the band was simply indicated as either 0 , trace, $1+, 2+, 3+$, or $4+$. employing in each instance a test tube of the same diameter in which to inspect the absorption spectrum of the solution, in accordance with Schumm's method (8).

Urobilinogen in the feces and urine was determined by means of Watson's modification (19) of Terwen's method (20).

\section{RESULTS}

The results are shown in Figures 1 to 12, inclusive. They indicate at least partial conversion of hematin to bile pigment. The data for the fecal urobilinogen excretion following hematin ad- ministration constitute the clearest evidence of conversion. The augmentation of the fecal urobilinogen after hematin injections was just as quantitative as after injection of comparable amounts of hemoglobin (in terms of the pigment fraction). This is seen in Figures 1 to 5 , inclusive. In at least 4 out of 5 experiments (Figures $1,2,4,5)$, the excess of urobilinogen excreted corresponded roughly with the amount of hematin injected. In 1 of the 5 experiments of this group (Figure 3 ) the findings are somewhat more difficult of interpretation. If the excess in this instance is calculated for the 4-day period after hematin injection, as was done in the other 4 experiments, then it amounts to but roughly 30 per cent of the amount injected. The excess for the first 2 days, however, was slightly more than 60 per cent of what might have been expected if all the hematin were excreted as urobilinogen. This brings up another question, i.e., whether an excess of pigment injected into, or formed in, an otherwise normal individual may be expected to reappear quantitatively as urobilinogen. The 


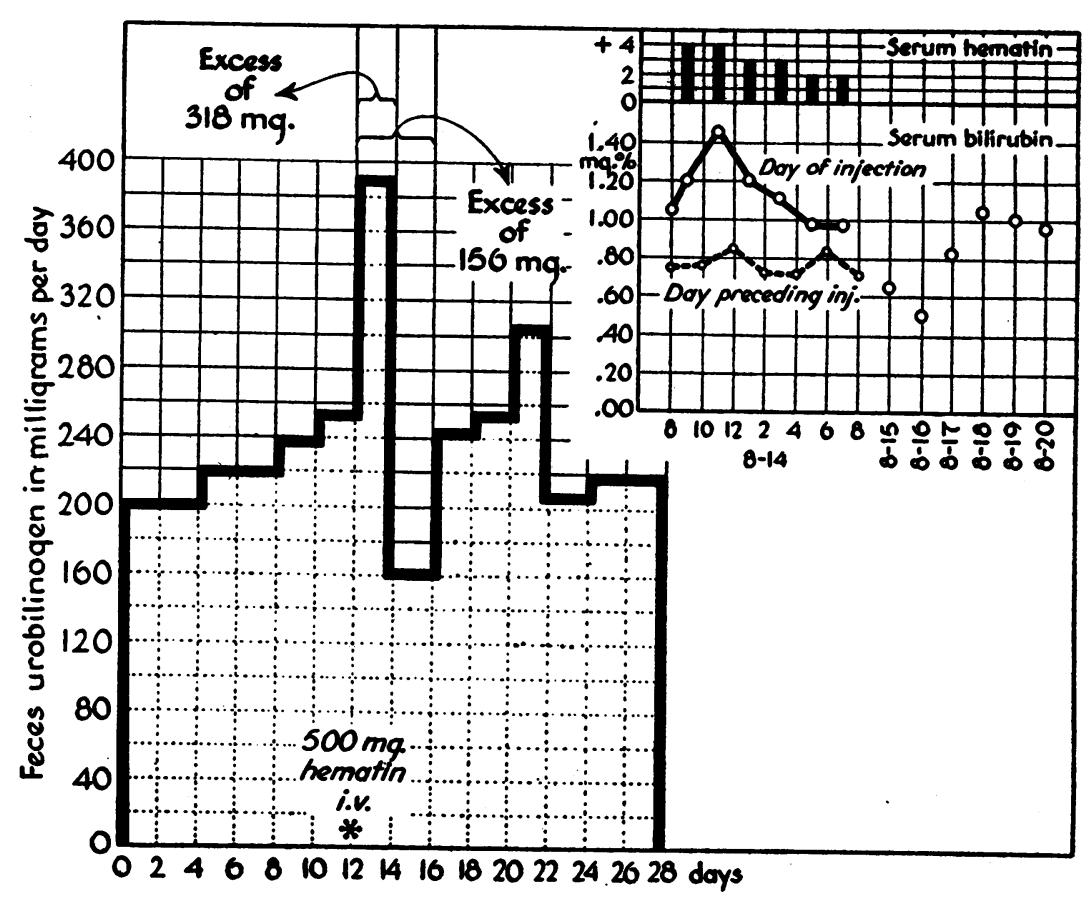

Fig. 3. Intravenous Injection of Hematin in a Normal Male Subject, S. S., AgE 20

The increase of the feces urobilinogen is from 30 to 60 per cent of the injected hematin, depending on the period for which the excess following injection is calculated. The levels of serum bilirubin are distinctly higher than on the days preceding or after the injection.

majority of the evidence on this point is in the affirmative $(1,21)$. While the calculation of the excess urobilinogen for a 4-day period, following hematin or hemoglobin injection, is perhaps open to question, the data shown in Figures 1 to 5 , inclusive, leave no doubt that the hematin gave rise to considerable amounts of bile pigment, as represented by the increased urobilinogen excretion. The data for the serum bilirubin following hematin injections, as shown in Figures 1 to 3, inclusive, and in Figure 6, is quite in accord with the belief that the hematin was converted to bilirubin. Figure 6 is of particular interest in revealing the different manner in which hemoglobin is handled, as compared with hematin, injection of the former resulting in a prompt sharp rise and fall of the serum bilirubin, while after hematin the increase was much smaller but more prolonged.

The observations in the patient with the total external biliary fistula (Figure 7) are very difficult of interpretation, principally because of the marked spontaneous fluctuation in bilirubin excre- tion in the bile. The principal criticism of this experiment is that the amounts of hematin injected were too small in the face of the fluctuant native bilirubin excretion just mentioned. The question arises as to whether any excess of bilirubin, derived from hematin, continues to be excreted for longer than 24 hours. If the excess is calculated for the first 24 hours only, then it is seen that the first injection of $100 \mathrm{mgm}$. was followed by an excess of $87 \mathrm{mgm}$. After the second injection of $200 \mathrm{mgm}$., however, the excess was but $35 \mathrm{mgm}$., very much less than might have been expected. Another disturbing fact in this experiment was the high level of $212 \mathrm{mgm}$. noted several days later, quite spontaneously. Thus it is evident that while the data in Figure 7 suggest some conversion of hematin to bilirubin, they are not conclusive.

The studies of the serum bilirubin after injection of hematin or hemoglobin, in jaundiced subjects, has provided somewhat conflicting data, as seen in Figures 8 to 12, inclusive. The evidence 


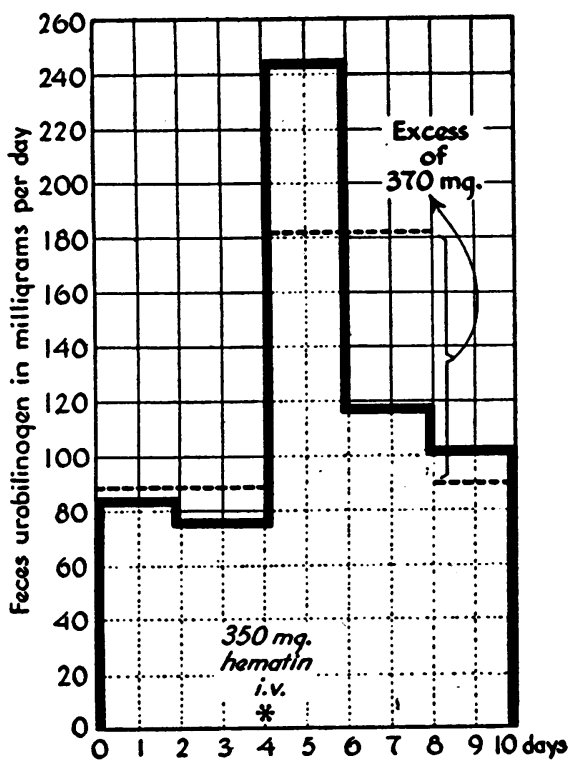

Fig. 4. Intravenous Injection of Hematin in a 28-year-old Female Subject, L. H., with Quiescent Cholecystitis and Choleltitiasas

The excess of the feces urobilinogen after the injection corresponds roughly with the amount injected.

in these experiments for conversion of hematin to bilirubin in the circulating blood is not uniformly convincing. The most carefully conducted ex-

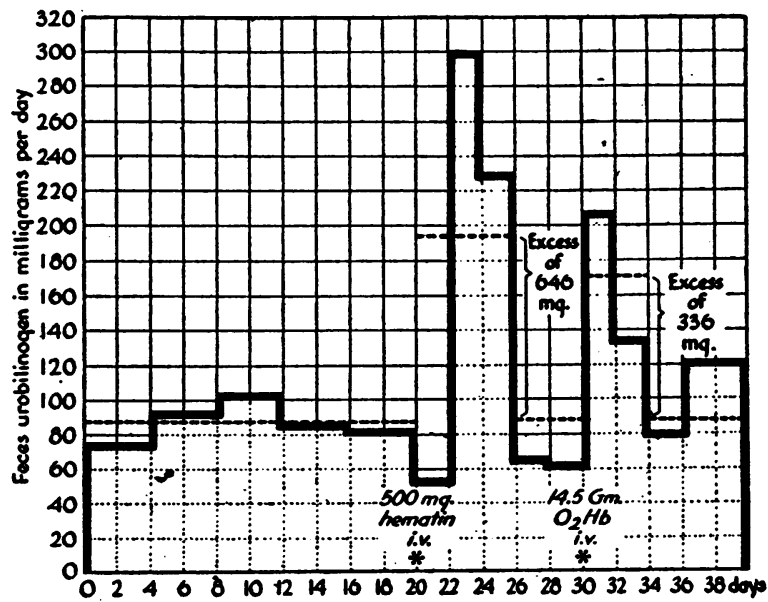

Fig. 5. Intravenous InJeCtion of Hematin and of Oxyhemoglobin, in Separate Experiments, in a Male Patient, Aged 60, Hospitalized Because of SponTANEOUS HYPOGLYCEMTA (ADENOMA OF Islands OF LANGERHANS)

The excess of the feces urobilinogen after the hematin injection is somewhat greater, and that after hemoglobin is smaller, than expected. In spite of this, it is clear that bile pigment was produced in both instances. periment of this group is shown in Figure 12, where it is seen that significant rises in serum bilirubin occurred after both hematin and hemoglobin, but again in somewhat more marked fashion after hemoglobin. Following each of these increases, a distinct augmentation in the urine bilirubin is observed. Whether this is significant cannot be determined with certainty, although the time sequence suggests that it is. An appreciable rise in serum bilirubin, following the hematin injection, is noted in Figures 8 and 11, but, in the former, the value is noted to be just as high on
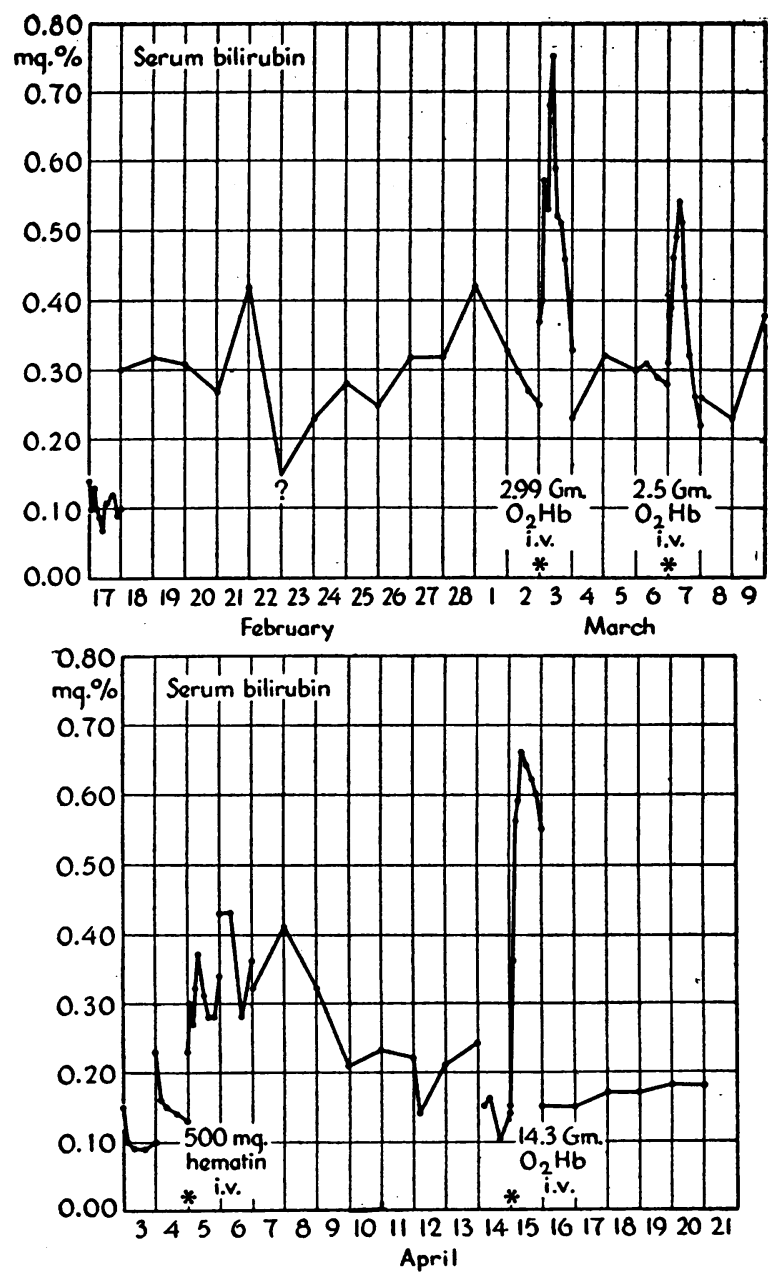

Fig. 6. Series of Experiments in a Male Patient, S. J., Age 60, with Spontaneous Hypoglycemia (Same INDIVIDUAL AS IN Fig. 5)

The sharp increases of the serum bilirubin after each injection of oxyhemoglobin, as compared with the flatter and less convincing rise in the curve after hematin, may be contrasted. 


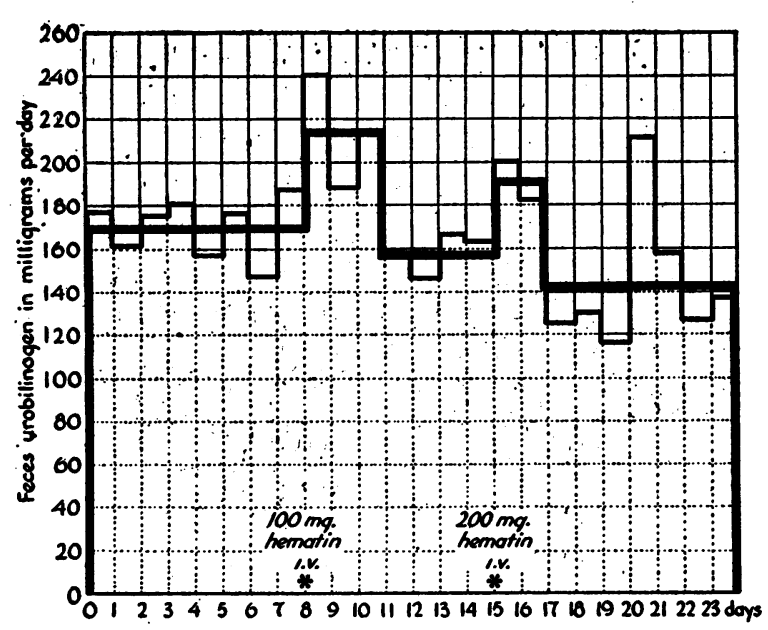

Fig. 7. Intravenous Injections of Hematin in a Female Subject, M. L., Age 52, Having a Total ExTERnal. Biliary Fistula

The heavy black line is the average for the entire period indicated. It is evident that the calculation of excesses is somewhat arbitrary, also that the excess after $200 \mathrm{mgm}$. was smaller than after $100 \mathrm{mgm}$. and that a marked spontaneous increase occurred a number of days later. The results here are regarded as of questionable significance.

the next day when hematin was not given. In the latter experiment (Figure 11), the rise in serum bilirubin was not reproducible with a second hematin injection a week later, although it may be noted that on the first occasion the rise was observed only 2 hours after the injection while on the subsequent occasion the serum was not examined until 4 hours afterwards. A similar criticism may be made of the other experiments of this group. No increase was observed in the experiment shown in Figure 9, again at 4-hour intervals after injection. In Figure 10, a distinct rise is seen, but not until 12 hours after the injection, so that it is of questionable significance.

\section{DISCUSSION}

The marked augmentation of urobilinogen in the feces following hematin injection in nonjaundiced subjects leaves no doubt that the hematin was converted to bilirubin and thence, after excretion in the bile and reduction in the intestinal tract, to urobilinogen. The evidence for rapid conversion of hematin to bilirubin in the circulating blood is not as clear. Sharp rises in serum bilirubin were noted after hemoglobin in-
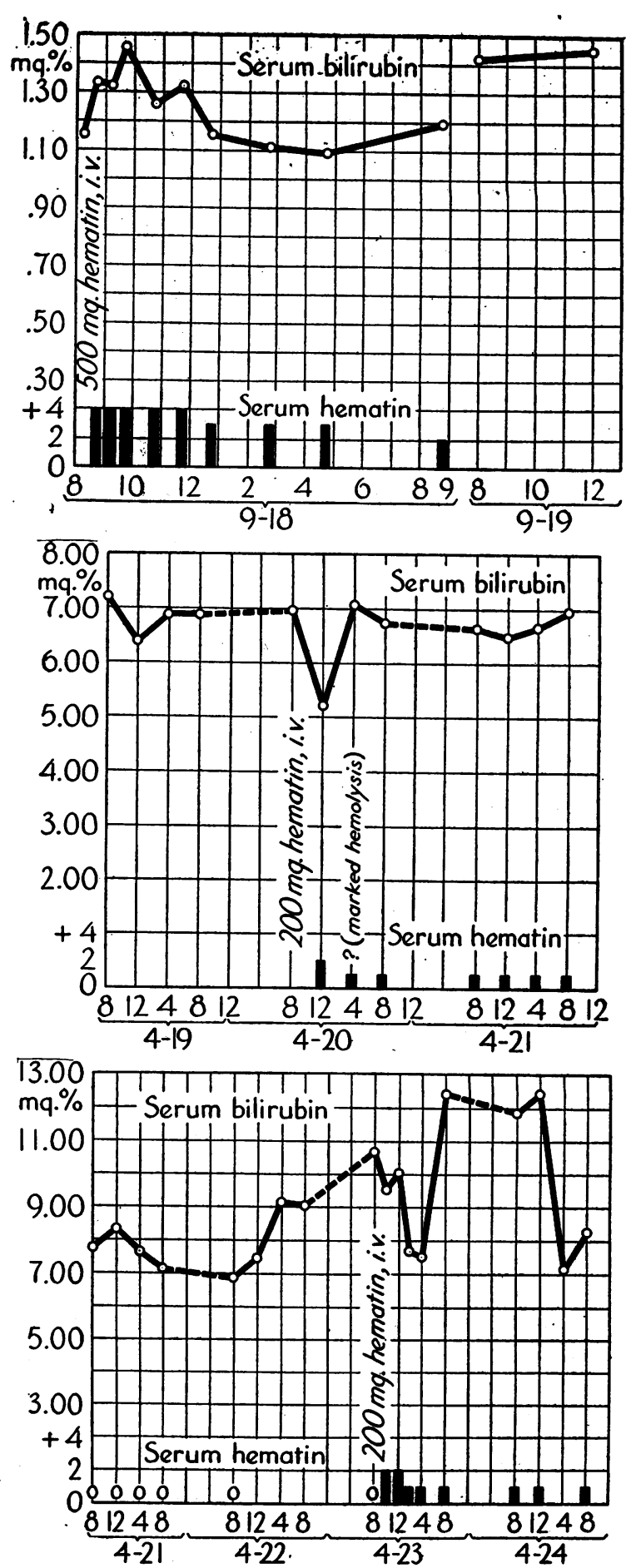

Fig. 8. Intravenous Injection of Hematin in a Male Subject, Age 58, Hospitalized Because of Chronic Glomerulonephritis

An apparent elevation of serum bilirubin is seen following the hematin, but on the next day the values were just as high without hematin. It may be noted, however, 


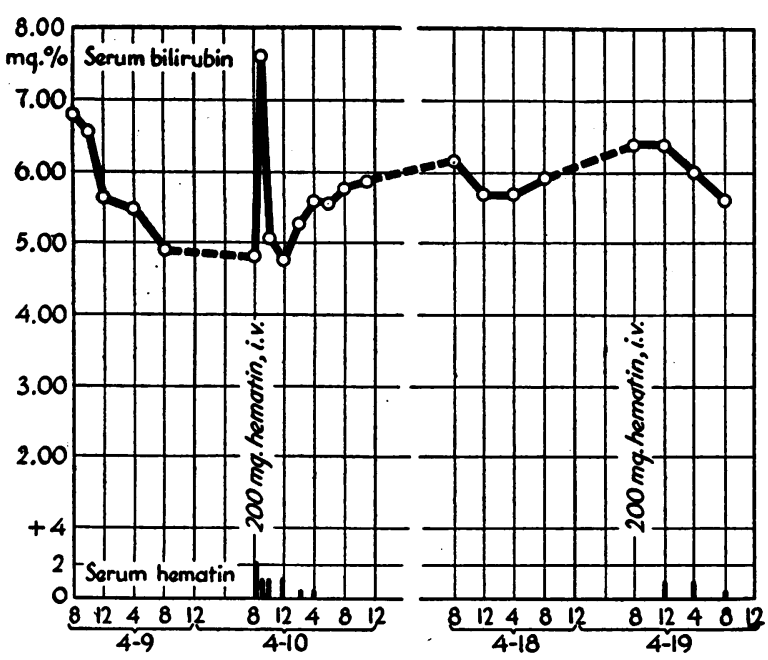

Fig. 11. Intravenous Injections of Hematin in a Male Subject; M. L., Age 52, Hospitalized Because of Complete Biliary Obstruction Due to Cancer of the Common Bile Duct

After the first injection, a brief transitory increase of serum bilirubin, of doubtful significance, is seen. Nothing of significance was observed in the second experiment.

jections, while the increase following hematin was not as uniform, nor when it did occur, as convincing, with one exception (Figure 12). The difference is not due to amount of available pigment introduced, since, on one occasion (Figure 6), a characteristic sharp rise is observed after but 2.5 grams of hemoglobin, equivalent to $100 \mathrm{mgm}$. of hematin; while on a different occasion, $500 \mathrm{mgm}$. of hematin produced only a slow and somewhat prolonged increase which might even be interpreted as nothing more than a cyclic variation. The data for serum bilirubin following hematin injecthat hematin was present in the serum at least until 9 p.m. on the 18th.

Fig. 9. Intravenous Injection of Hematin in a Female Subject, B. E., Age 68, Hospitalized Because of Complete Biliary Obstruction Due to Cancer OF THE Pancreas

In this instance, a temporary drop in serum bilirubin is seen following the hematin. The long persistence of the latter in the serum is noted.

Fig. 10. Intravenous Injection of Hematin in a Male Subject, W. B., Age 69, Hospitalized Because of Complete Biliary Obstruction Due to Cancer of the Pancreas

A transitory decline followed by a considerable increase in serum bilirubin is seen, following the hematin. Persistence of hematin in the serum into the second 24 hours is noted. tions, as shown in Figures 1, 2, 3, 6, 11, and 12, may be accepted as supporting a conversion of hematin to bilirubin. That noted in Figures 8, 9, and 10 is equivocal and might readily enough be interpreted as supporting the conclusions of Bingold and Duesberg, which have already been mentioned. These data do not exclude, however, a removal of hematin by the liver with subsequent conversion to bilirubin and biliary excretion as first suggested by Aschoff (22). In the subjects with obstructive jaundice, biliary excretion would not be expected, and, as Duesberg pointed out, a conversion of hematin to bilirubin ought to be followed here by an elevation of the serum bilirubin. This assumes, however, that any excess formed in this way is not rapidly excreted in the urine, a possible source of loss which has not hitherto been taken into account. In the 2 experiments shown in Figure 12, 1 with hematin and 1 with hemoglobin, distinct increases in serum bilirubin are seen which are followed by significant increases in urinary bilirubin. The increase of the serum bilirubin after hematin, although distinct, was not as striking as that after hemoglobin,

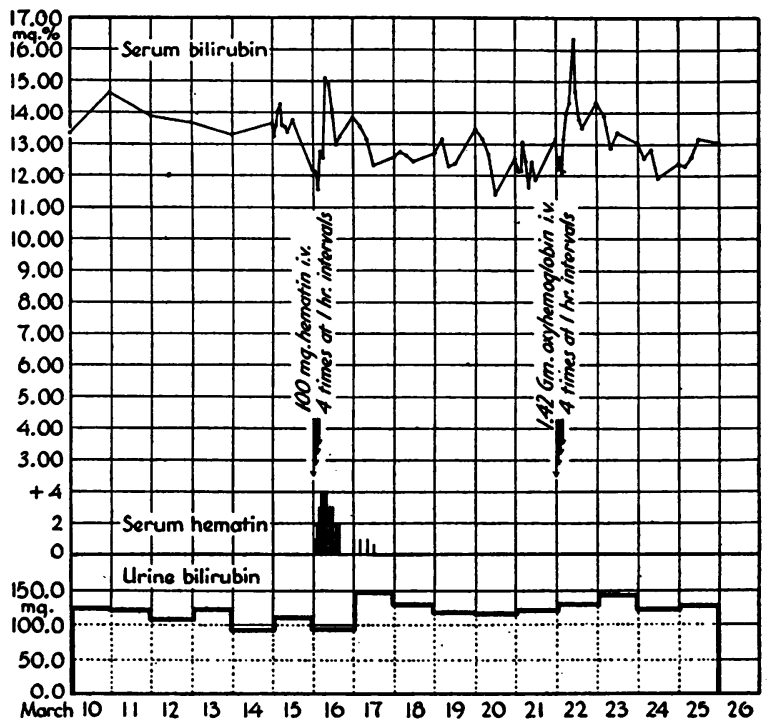

Fig. 12. Repeated Intravenous Injections of Hematin and of Hemoglobin in Separate Experiments in a Male Subject, J. H., Age 55, Hospitalized Because of Complete Biliary Obstruction Due to CanCer of THE Pancreas

Distinct increases of the serum bilirubin are observed after injection of each of the two substances. Suggestive increases of the urine bilirubin are likewise noted. 
again in spite of the fact that the amount of hematin injected was about 40 per cent larger. The results of this experiment are regarded as the most significant of any in this group. It is quite possible that the lack of elevation of serum bilirubin following hematin in other experiments (Figures 9 and 10) was due in part to an increased excretion (of bilirubin) in the urine. Another factor may be that of a very slow conversion of hematin to bilirubin as contrasted with a more rapid one for hemoglobin. With respect to the latter possibility, the long persistence (20 to 36 hours) of hematin in the serum, after injection, indicates a slow rate either of conversion or of removal. This may very well be related to the formation of Fairley's methemalbumen (10). Unfortunately, data were not obtained in the present studies on the disappearance rate of hemoglobin, so that direct comparisons are impossible. It is well known, however, that hemoglobin disappears from the circulation relatively rapidly even if concentrations below the renal threshold are considered. Furthermore, the rapid increases of serum bilirubin after injection of hemoglobin, as noted particularly in Figure 6, indicate the speed with which hemoglobin might be expected to disappear.

A very slow conversion of hematin to bilirubin, either in the blood or the liver, would adequately explain Duesberg's failure to note any increase in bilirubin in duodenal drainage samples obtained over relatively short periods.

\section{SUMMARY AND CONCLUSIONS}

1. Following intravenous administration of hematin in non-jaundiced human subjects, an augmentation of the feces urobilinogen was observed which was roughly proportional to the amount of hematin given. This is interpreted as evidence of formation of bile pigment from hematin, contrary to the views of Bingold and Duesberg who believe that hematin is not converted to bilirubin.

2. The serum bilirubin was not uniformly elevated following the hematin injections, in contrast with those of hemoglobin which regularly produced sharp rises. Nevertheless, significant elevations were noted after hematin in a number of experiments. A relatively slow conversion of hematin to bilirubin is suggested by the long persistence of hematin in the circulating blood. This may be related to formation of methemalbumen. Increased excretion of bilirubin in the urine may account in part for failure of the serum bilirubin to rise after hematin injections in subjects with complete biliary obstruction.

\section{BIBLIOGRAPHY}

1. Watson, C. J., The pyrrol pigments, with particular reference to normal and pathologic hemoglobin metabolism. Handbook of Hematology, by $\mathrm{Hal}$ Downey, v. IV, p. 2447. Paul Hoeber and Co., New York, 1938.

2. a. Brugsch, T., and Kawashima, K., Der Einfluss von Hämatoporphyrin, Hämin, und Urobilin auf die Gallenfarbstoffbildung. Ztschr. f. exper. Path., 1911, 8, 645.

b. Brugsch, T., and Yoshimoto, Zur Frage der Gallenfarbstoffbildung aus Blut. Ztschr. f. exper. Path., 1911, 8, 639.

c. Brugsch, T., and Retzlaff, K., Blutzerfall, Galle, und Urobilin. Zur Frage der Gallenfarbstoffbildung aus Blut. Ztschr. f. exper. Path., 1912, 11, 508.

d. Brugsch, T., and Pollak, E., UUber die Umwandlung von Blutfarbstoff in Gallenfarbstoff. Biochem. Ztschr., 1924, 147, 253.

3. Fischer, H., and Lindner, F., Utber den Umbau des Blutfarbstoffes durch Hefe. Ztschr. f. physiol. Chem., 1926, 153, 54.

4. Warburg, O., and Negelein, E., Grünes Hämin aus Blut-Hämin. Ber. d. deutsch. chem. Gesellsch., 1930, 63, 1816.

5. Barkan, G., Blutfarbstoff, Eisen, Gallenfarbstoff ; neuere Untersuchungen über eisenhaltige Begleiter des Hämoglobins. Klin. Wchnschr., 1937, 16, 1265.

6. Lemberg, R., Legge, J. W., and Lockwood, W. H., Haemoglobin from bile pigment. Nature, 1938, 142, 148.

7. Engel, M., Quantitative Untersuchungen zur Gallenfarbstoffbildung in vitro. Ztschr. f. physiol. Chem., 1940, 266, 135.

8. a. Schumm, $O$., Hämatin als pathologischer Bestandteil des Blutes. Ztschr. f. physiol. Chem., 1916, 97, 32.

b. Chemie der Erythrozyten und des Hämoglobins. In: Hirschfeld, H., and Hittmair, A., Handb. d. allg. Hämatologie. Berlin, Urban and Schwarzenberg, I, erste Hälfte, p. 99, 1932.

9. a. Duesberg, R., Utber die biologischen Beziehungen des Hämoglobins zu Bilirubin und Hämatin bei normalen und pathologischen Zuständen des Menschen. Arch. f. exper. Path. u. Pharmakol., 1934, 174, 305. 
b. Duesberg, R., Uber den Auf- und Abbau des Blutfarbstoffes. Klin. Wchnschr., 1938, 17, 1353.

10. Fairley, N. H., Methaemalbumin; clinical aspects. Quart. J. Med., 1941, 10, 95.

11. a. Anderson, W. A. D., and Morrison, D. B. Role of parasite pigment (ferrihemic acid) in production of lesions in malaria. Arch. Path., 1942, 33, 677.

b. Morrison, D. B., and Anderson, W. A. D., The pigment of the malaria parasite. Pub. Health Rep., 1942, 57, 90.

12. Bingold, $K$., Blutstoffwechsel. In Hirschfeld, $H$., and Hittmair, A., Handb. d. allg. Hämatol. Berlin, Urban and Schwarzenberg. I, erste Hälfte, p. 601, 1932.

13. Gitter, A., and Heilmeyer, L., Klinische Farbmessungen. XI. Der Einfluss parenteraler Gaben von Hämoglobin und Hämoglobinabbauprodukten auf den Blutfarbstoffwechsel mit besonderer Berücksichtigung der Harnfarbstoffausscheidung. Ztschr. f. d. ges. exper. Med., 1931, 77, 594.

14. Duesberg, R., and Hagenbeck, H., Die Hämoglobinbelastung als Leberfunktionsprüfung. Deutsches Arch. f. klin. Med., 1938, 182, 22.

15. Fischer, H., and Orth, H., Die Chemie des Pyrrols, Bd. II, I. Hälfte, Akad. Verlagsgesellsch., Leipzig, 1937.

16. Heilmeyer, L., Blutfarbstoffwechselstudien; Probleme, Methoden und Kritik der Whippleschen
Theorie. Deutsches Arch. f. klin. Med., 1931, 171, 123.

17. Watson, C. J., Pass, I. J., and Schwartz, S., A study of the supposed conversion of protoporphyrin to coproporphyrin by the liver. I. The fate of parenterally administered protoporphyrin in dogs with bile renal fistulae. J. Biol. Chem., 1941, 139, 583.

18. Jendrassik, L., and Czike, A., Bestimmung des Bilirubins im Blute. Ztschr. f. d. ges. exper. Med., 1928, 60, 554.

19. Watson, C. J., Studies of urobilinogen. I. An improved method for the quantitative estimation of urobilinogen in urine and feces. Am. J. Clin. Path., 1936, 6, 458.

20. Terwen, A. J. L., Uber ein neues Verfahren zur quantitativen Urobilinbestimmung in Harn und Stuhl. Deutsches Arch. f. klin. Med., 1925, 149, 72.

21. a. Sribhishaj, K., Hawkins, W. B., and Whipple, G. H., I. Bile pigment and hemoglobin interrelation in normal dogs. Am. J. Physiol., 1931, 96, 449

b. Hawkins, W. B., and Whipple, G. H., The life cycle of the red blood cell in the dog. Ibid., 1938, 122, 418.

22. Aschoff, L., Utber Bildungs- und Ausscheidungsstörungen der Gallenfähigen Substanzen (Dyscholie), besonders des Gallenfarbstoffs (Ikterus). Acta path. et microbiol. Scandinav., 1928, 5, 338. 